\title{
IDENTIFIKASI MODEL SELF-EXCITING THRESHOLD AUTOREGRESSIVE DENGAN SWITCHING TWO REGIME (KASUS PADA DATA EKSPOR AGRIKULTUR DI INDONESIA)
}

\section{Identification of Self-Exciting Threshold Autoregressive Model with Two Regime Switching (Case on Agriculture Export Data in Indonesia)}

\author{
Husnun Nur Ghiffari Putri Riyansyah ${ }^{1}$, Dewi Retno Sari Saputro ${ }^{2 *}$, Bowo Winarno $^{3}$ \\ 1,2,3 Program Studi Matematika, Fakultas Matematika dan Ilmu Pengetahuan Alam, Universitas Sebelas Maret \\ Jl. Ir. Sutami No. 36A Kentingan Jebres Surakarta Jawa Tengah, Indonesia \\ e-mail: ${ }^{1}$ husnun.or.ghiffari@gmail.com; ${ }^{2 *}$ dewiretnoss@staff.uns.ac.id; ${ }^{3}$ bowowinarno@staff.uns.ac.id \\ Corresponding Author*
}

\begin{abstract}
Abstrak
Salah satu model runtun waktu yang menjelaskan perubahan struktur sebagai akibat terjadinya lompatan beberapa data dalam satu kurun waktu tertentu yakni model Threshold Autoregressive (TAR). Dasar model TAR adalah penggunaan regime yang berbeda dalam analisis autoregressive. Model Self-Exciting Threshold Autoregressive (SETAR) merupakan salah satu model dengan basis TAR dengan parameter delay setiap regimenya sama. Model SETAR bersifat linier pada setiap regime dan nonlinier apabila model pada setiap regime digabung. Selain itu, model tersebut dapat menangkap lompatan data yang tidak dapat ditangkap oleh model deret waktu linier. Hal ini berarti model SETAR memiliki tingkat fleksibilitas tinggi dalam parameter melalui perilaku switching regime sehingga sesuai untuk diaplikasikan pada data ekspor agrikultur di Indonesia. Tujuan penelitian ini mengkaji estimasi parameter model SETAR dan menerapkannya pada data ekspor agrikultur Indonesia. Dalam meduga parameter model SETAR ada tiga metode yang dapat dilakukan, yaitu metode sequential conditional least squares, Ordinary Least Square (OLS) serta Nonlinier Least Squares (NLS). Dalam penelitian ini digunakan metode estimasi parameter dua tahap dengan OLS dan estimasi parameter tahap kedua digunakan untuk mengoptimalkan nilai parameter yang tidak signifikan pada model. Pada penerapannya, diperoleh model SETAR $(2,1,1)$ untuk memodelkan data ekspor agrikultur di Indonesia dengan nilai MAPE $25 \%$.
\end{abstract}

Kata kunci: TAR, SETAR, SETAR (2,1,1), nonlinear, estimasi parameter, OLS, agrikultur

\begin{abstract}
A time series model that explain the structural changes associated with data in a certain time period is the Threshold Autoregressive (TAR) model. The basic of the TAR model there are some different usage regimes in autoregressive analysis. One model based on TAR is a self-exciting threshold autoregressive (SETAR) model with the same delay parameters for each regimen. The SETAR model has a linear nature in each regime but being nonlinear if the models of each regime are combined. In addition, this model can improve jump data that cannot be captured by linear time series models. This means that the SETAR model has high-level parameters through an appropriate switching regime that is applied to agricultural export data in Indonesia. The purpose of this reseach is to test the estimated SETAR parameter model and apply it to Indonesian agricultural export data. There are three methods that can be done for estimating of parameter of SETAR model, namely the conditional quadratic sequential method, ordinary least square $(O L S)$ and nonlinear least square $(N L S)$. In this research, the two stage parameter estimation method is used with OLS and the second stage parameter estimation is used to optimisze the parameter values that are not significant in the model. In its application, the SETAR model $(2,1,1)$ was obtained to model agricultural export data in Indonesia and the MAPE value was $25 \%$.
\end{abstract}

Keywords: TAR, SETAR, SETAR (2,1,1), nonlinear parameter estimation, OLS, agriculture. 


\section{PENDAHULUAN}

Analisis deret waktu (time series) adalah suatu analisis statistik yang dapat diterapkan pada data yang berhubungan dengan waktu. Analisis deret waktu bertujuan untuk menemukan pola data yang terkait dengan data pada masa lalu yang dituliskan dalam bentuk persamaan matematika (model) [15]. Pada umumnya pemodelan deret waktu ini dikaitkan dengan proses peramalan yaitu suatu perkiraan masa yang akan datang berdasarkan keadaan masa lalu. Pemilihan model peramalan pada saat menganalisis data deret waktu mempunyai pengaruh yang sangat besar terhadap keakuratan dan kevalidan hasil ramalan serta keputusan yang akan diambil dari hasil tersebut. Model-model peramalan yang dimaksudkan antara lain moving average, naive, exponential smoothing, holt, dan winter [10,16]. Model-model tersebut digunakan untuk data yang terdapat hubungan linear antara data sekarang dan data masa lalu.

Selain itu, terdapat model autoregressive (AR). Model AR adalah model deret waktu linear yang hanya berdasarkan data histori yang diamati. Model AR dapat dikembangkan menjadi model autoregressive moving average (ARMA) dan model autoregressive integreted moving average (ARIMA). Namun, modelmodel tersebut hanya digunakan untuk peramalan jangka pendek. Spesifikasi nonlinier mulai dianggap sebagai representasi data yang lebih realistik. Metode deret waktu Treshold Autoregression (TAR), Self Exiting Treshold Autoregression (SETAR) dan Markov Switching memberikan hasil peramalan yang baik dalam kasus-kasus ini [1]. Model nonlinear pada time series antara lain model threshold regression (TR) dan threshold autogressive (TAR). Model TR menggambarkan bentuk sederhana dari regresi nonlinear yang menampilkan grafik sepotong-sepotong (piecewise) spesifikasi linear dan pergantian (switching) regime yang terjadi ketika terdapat variabel yang diamati melewati ambang yang ditentukan. Selain itu, model TR tidak menggunakan unsur AR untuk pergantian regime. Berbeda dengan model TAR, model SETAR adalah model nonlinear yang didasarkan unsur AR dan mengggunakannya untuk pergantian regime [6]. Model TAR pertama kali diperkenalkan oleh Tong pada tahun 1983 [8]. Menurut [3], model TAR merupakan model autoregressive (AR) tersegmen sehingga diantara regime yang berbeda dimungkinkan untuk mempunyai model AR yang berbeda.

$$
Z_{t}=\left\{\begin{array}{c}
\varphi_{0,1}+\sum_{i=1}^{p_{1}} \varphi_{i, 1} Z_{t-i}+\varepsilon_{t, 1} \quad \text { jika } s_{t-d} \leq r_{1} \\
\varphi_{0,2}+\sum_{i=1}^{p_{2}} \varphi_{i, 2} Z_{t-i}+\varepsilon_{t, 2} \text { jika } r_{1}<s_{t-d} \leq r_{2} \\
\vdots \\
\varphi_{0, m}+\sum_{i=1}^{p_{m}} \varphi_{i, m} Z_{t-i}+\varepsilon_{t, m} \text { jika } s_{t-d}>r_{(m-1)}
\end{array}\right.
$$

dengan $Z_{t}$ adalah variabel dependen pada waktu ke- $t, Z_{t-i}$ adalah variabel independen, $\varphi_{0,1}$ adalah konstanta pada regime ke-1, $\varphi_{0,2}$ adalah konstanta pada regime ke-2, $\varphi_{0, m}$ adalah konstanta pada regime ke-m, $\varphi_{i, 1}$ adalah parameter model AR ke- $i$ pada regime $\mathrm{ke}-1, \varphi_{i, 2}$ adalah parameter model AR ke- $i$ pada regime ke-2, $\varphi_{i, m}$ adalah parameter model AR ke- $i$ pada regime ke-m, $\varepsilon_{t, 1}$ adalah error pada waktu ke-t regime ke-1, $\varepsilon_{t, 2}$ adalah error pada waktu ke-t regime ke-2, $\varepsilon_{t, m}$ adalah error pada waktu ke-t regime ke-m $\left(\varepsilon_{t} \sim N\left(0, \mathrm{o}_{\varepsilon}^{2}\right)\right.$, dan $r_{1}, r_{2}, \ldots, r_{m-1}$ adalah nilai threshold, $\mathrm{d}$ adalah parameter delay.

Pengembangan model TAR adalah model self-exciting threshold autoregressive (SETAR). Berbeda dengan model TAR, model SETAR dapat mengidentifikasi parameter delay yang sama pada setiap regime. Model SETAR menunjukkan kinerja yang lebih baik daripada model linier dan nonlinear lainnya [2,13]. Keistimewaan model SETAR dapat membangkitkan dinamika nonlinear yang kompleks dan dapat menghasilkan lompatan data yang tidak ditangkap oleh model deret waktu yang lainnya $[4,5]$. Beberapa penelitian yang sukses menggunakan model SETAR adalah pada [2], [7], [14], [17], [18].

Model SETAR adalah kasus khusus model TAR apabila threhold yang digunakan diambil dari nilai deret waktu itu sendiri. Model SETAR adalah keluarga model runtun waktu nonlinear dengan parameter delay tiap regime-nya sama. Model SETAR memiliki keistimewaan yaitu dapat menangkap loncatan data yang tidak dapat ditangkap oleh model deret waktu linear. Model SETAR juga ditentukan oleh order autoregressive $(p)$, jumlah regime $(m)$, parameter delay, dan threshold. Model SETAR $m$ regime ditulis sebagai $\left(m, p_{1}, p_{2}, \ldots, p_{m}\right)$ yakni 


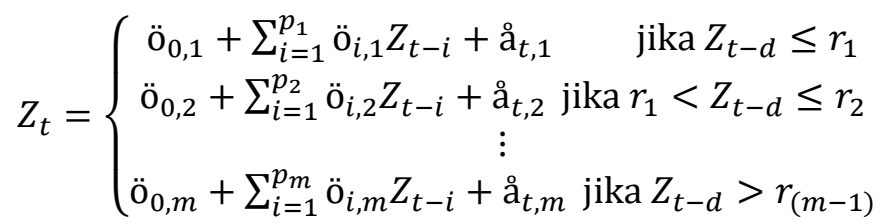

dengan $Z_{t}$ adalah variabel dependen pada waktu ke- $t, Z_{t-1}, Z_{t-2}, Z_{t-3}, \ldots, Z_{t-p}$ adalah variabel independen dari $Z_{t}, \ddot{o}_{0, i}$ adalah konstanta pada regime ke-j, $\ddot{o}_{i, j}$ adalah parameter model AR ke $-i$ pada regime ke-j, $\stackrel{\mathrm{a}}{t, j}$ adalah error pada waktu ke-t regime ke-j $\left(\stackrel{\circ}{a}_{t} \sim N\left(0, o_{a}^{2}\right)\right.$, dan $r_{1}, r_{2}, \ldots, r_{m-1}$ adalah nilai threshold, d adalah parameter delay.

Estimasi parameter model pada umumnya menjadi tujuan kajian penelitian model, demikian juga model SETAR. Beberapa kajian telah melakukan estimasi tersebut yakni [7], [17] menggunakan metode kuadrat terkecil (MKT) untuk estimasi model SETAR. MKT tidak memerhatikan nilai parameter yang tidak signifikan, mengakibatkan estimator yang dihasilkan tidak merepresentasikan populasi. Oleh karena itu diperlukan satu tahapan lagi untuk memperoleh hasil estimasi parameter yang optimal. Terkait uji dan sifatsifat MKT pada model berbasis AR telah dibahas pada $[9,11]$.

Di Indonesia terdapat dua komoditas ekspor yaitu migas dan nonmigas. Diantara keduanya ekspor nonmigas memberikan sumbangan devisa yang lebih besar dibandingkan dengan ekspor migas. Saat ini, pemerintah mengurangi ketergantungan ekonomi terhadap ekspor migas sebab harga komoditas migas meningkat [19] dan pemerintah sedang berusaha untuk meningkatkan ekspor pada komoditas nonmigas, khususnya pada sektor agrikultur. Data ekspor agrikultur termasuk data runtun waktu yang dapat diterapkan dalam model runtun waktu. Menurut [20], model runtun waktu adalah model statistik yang berhubungan dengan waktu. Dalam model runtun waktu terdapat model linear dan model nonlinear. Kelemahan model linear tidak dapat mengakomodasi data yang fluktuatif. Untuk mengatasi permasalahan tersebut digunakanlah model nonlinear dalam hal ini model yang dipergunakan adalah model threshold autoregressive (TAR). Oleh karena itu, pada penelitian ini diturunkan ulang estimasi model SETAR dengan MKT dua tahap dan penerapannya pada data ekspor agrikultur di Indonesia.

\section{METODE PENELITIAN}

Penelitian ini merupakan penelitian teori dan terapan yaitu mengidentifikasi model SETAR dan menerapkannya pada data ekspor agrikultur Indonesia. Metode penelitian dibagi menjadi dua bagian. Bagian pertama adalah data penelitian dan bagian kedua adalah langkah penelitian.

\subsection{Data Penelitian}

Penelitian ini menggunakan data sekuder, yaitu data ekspor agrikultur Indonesia dari periode Januari 2007 sampai dengan Desember 2019 [12]. Dalam penelitian ini digunakan sebanyak 138 data pengamatan in sample dari periode Januari 2007 sampai dengan Desember 2019 dan data pengamatan out sample digunakan sebanyak 6 data pengamatan dari periode Januari 2019 hingga Desember 2019. Data pengamatan in sample digunakan untuk pemodelan model SETAR, sedangkan data pengamata out sample dilakukan untuk validasi model SETAR.

\subsection{Langkah Penelitian}

Langkah pertama yang dilakukan dalam penelitian ini untuk mencapai tujuan adalah melakukan kajian ilmu secara teoritis mengenai model AR. Selanjutnya, melakukan kajian ilmu secara teoritis mengenai model SETAR dan estimasi parameternya. Langkah selanjutnya ialah menentukan persamaan error, kemudian menentukan persamaan jumlah kuadrat error dan meminimumkannya. Selanjutnya, menentukan estimator tahap pertama, kemudian melakukan pengecekan apakah terdapat estimator yang tidak siginifikan. Jika terdapat estimator yang tidak signifikan maka menentukan estimator tahap kedua dan diperoleh secara teoritis. Namun, jika tidak terdapat estimator yang tidak signifikan, maka dilanjutkan dengan input data. Data yang diinputkan adalah data ekspor agrikultur Indonesia yang selanjutya diplotkan untuk mengidentifikasi pola datanya. Langkah selanjutnya adalah melakukan hipotesis stasioneritas terhadap variansi, kemudian melakukan pengecekan apakah data stasioner terhadap variansi, jika tidak melakukan transformasi Box-Cox dan melakukan pengecekan kembali apakah data stasioner terhadap variansi. Namun, jika data sudah stasioner terhadap variansi maka dilakukan uji hipotesis stasioneritas stasioneritas terhadap rata-rata. Selanjutnya, dilakukan pengecekan apakah data sudah stasioner terhadap rata-rata, jika ya tidak maka 
dilakukan differencing dan melakukan pengecekan kembali apakah data sudah stasioner terhadap rata-rata. Namun, jika data sudah stasioner terhadap rata-rata maka membuat plot ACF dan PACF, serta menentukan order maksimum AR. Selanjutnya, melakukan uji hipotesis Terasvirta dan melakukan pengecekan apakah data bersifat nonlinear, jika tidak maka harus dilakukan pemodelan linear. Namun, jika ya maka menentukan delay dan threshold berdasarkan kriteria AIC. Kemudian mengonstruksikannya ke model SETAR dan melakukan estimasi parameter tahap 1. Langkah selanjutnya adalah melakukan uji signifikansi dan melakukan pengecekan apakah terdapat estimator yang tidak signifikan, jika ya maka menentukan estimator tahap ke-2 dan melakukan uji signifikansi kembali. Namun, jika tidak ada maka mengonstruksi model SETAR dan diperoleh model SETAR dengan data ekspor agrikultur Indonesia. Selanjutnya, dilakukan uji asumsi white noise dan melakukan pengecekan apakah error memenuhi asumsi white noise. Jika error tidak memenuhi asumsi white noise maka dilakukan transformasi data dan kembali ke langkah melakukan uji hipotesis stasioneritas terhadap rata-rata. Namun, jika error memenuhi asumsi white noise maka melakukan uji asumsi kenormalan dan mengecek apakah error memenuhi asumsi kenormalan. Jika error tidak memenuhi asumsi kenormalan maka dilakukan transformasi data dan kembali ke langkah melakukan uji hipotesis stasioneritas terhadap rata-rata. Namun, jika error memenuhi asumsi kenormalan maka melakukan validasi model SETAR dengan menghitung MAPE. Selanjutnya melakukan analisis model SETAR yang telah diperoleh.

Langkah-langkah yang telah disebutkan pada penjelasn di atas dapat digambarkan dalam diagram alir seperti pada Gambar 1, sebagai berikut.

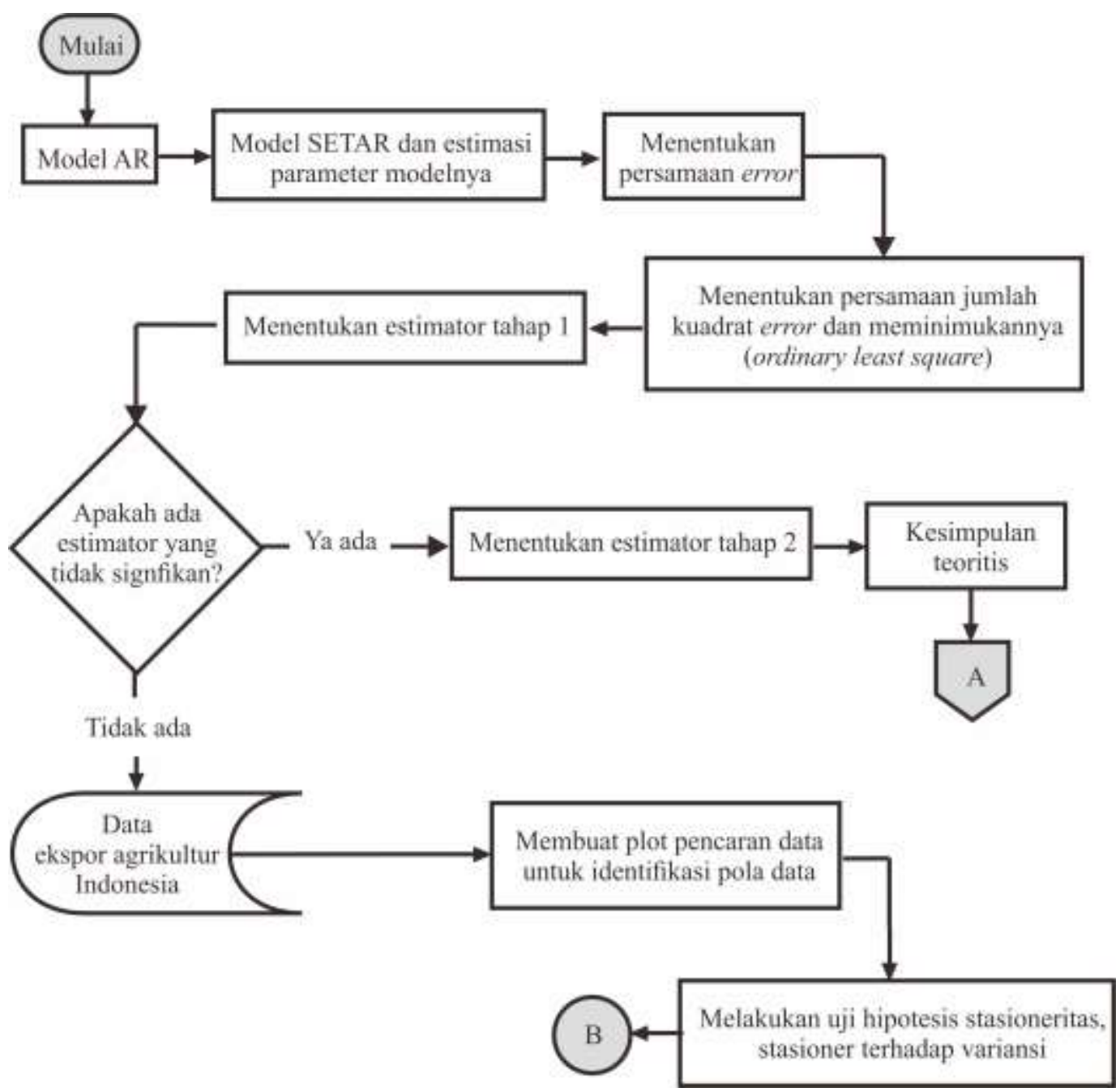

Gambar 1. Diagram Alir Penelitian 
Lanjutan Gambar 1.

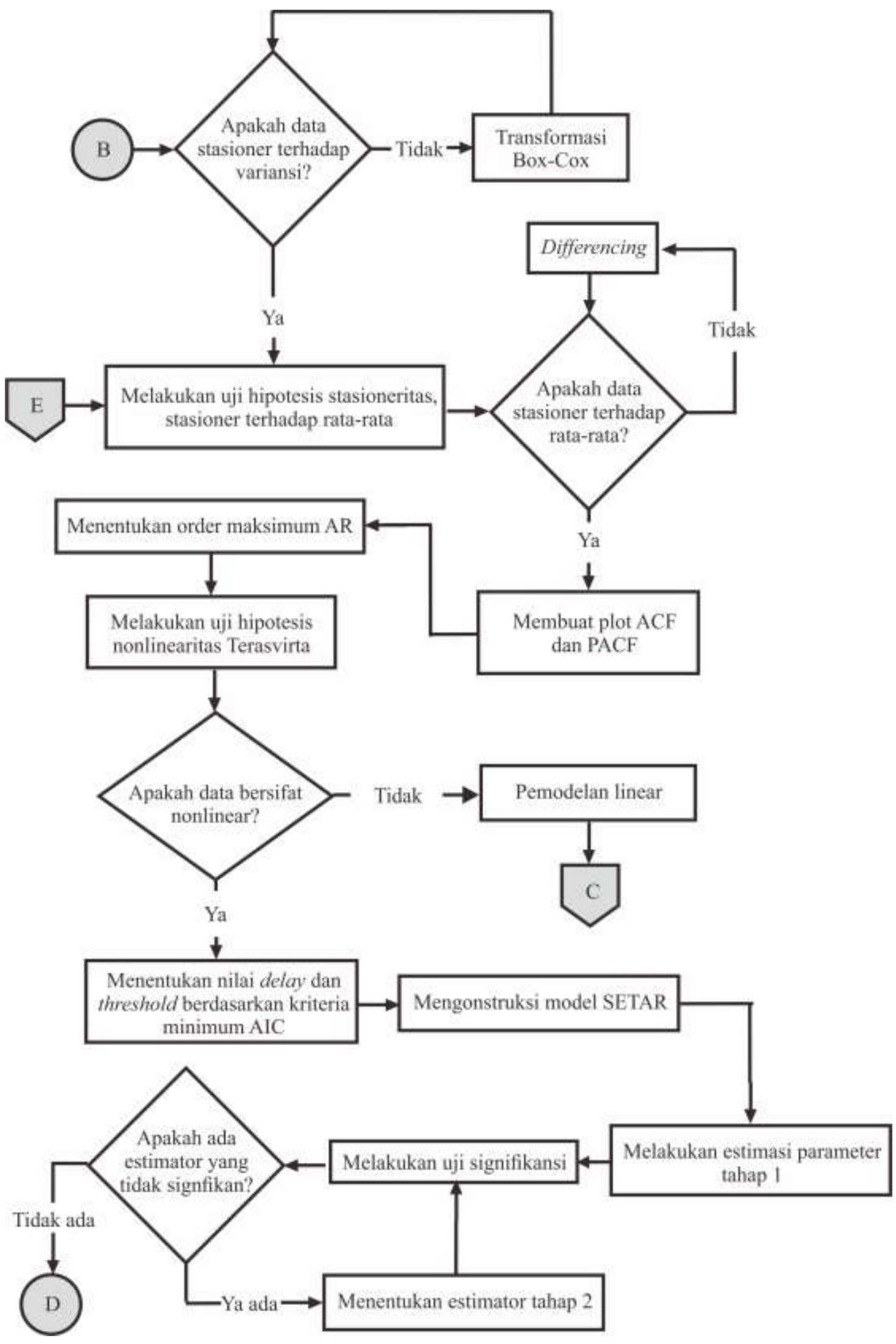


Lanjutan Gambar 1.

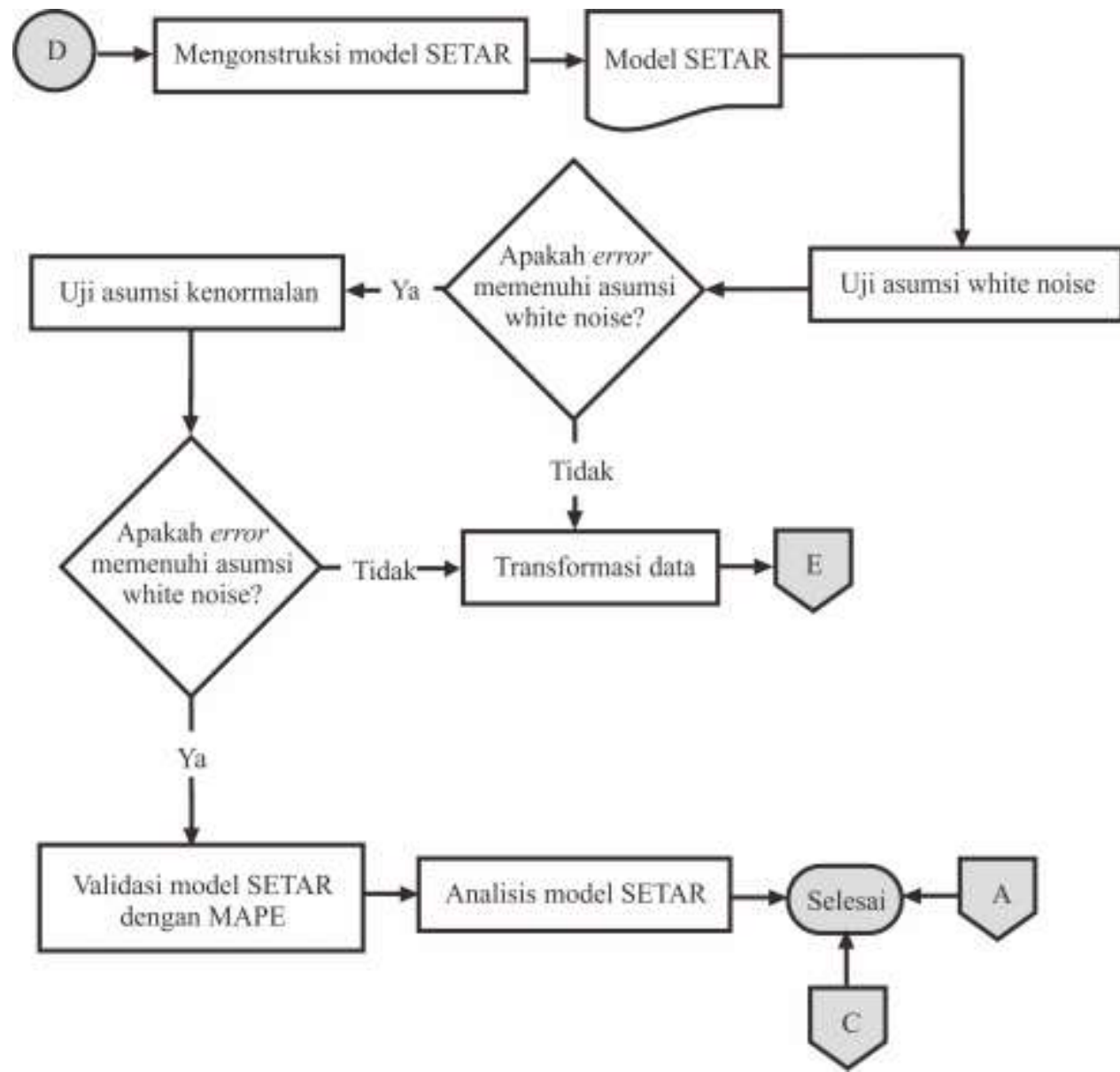

\section{HASIL DAN PEMBAHASAN}

\subsection{Model SETAR dengan 2 regime $\left(2, p_{L}, p_{U}\right)$}

Order autoregressive pada SETAR dengan dua regime (bagian) dapat dibagi menjadi dua yaitu order autoregressive regime bawah (lower) dan order autoregressive regime atas (upper) atau $\mathrm{L}$ dan $\mathrm{U}$ dengan persamaan yang ditulis sebagai

$$
Z_{t}= \begin{cases}\ddot{\mathrm{o}}_{0,1}+\sum_{i=1}^{p_{1}} \ddot{\mathrm{o}}_{i, 1} Z_{t-i}+\stackrel{\mathrm{a}}{t, 1}^{p_{0}} & \text { jika } Z_{t-d} \leq r_{1} \\ \ddot{\mathrm{o}}_{0,2}+\sum_{i=1}^{p_{2}} \ddot{\mathrm{o}}_{i, 2} Z_{t-i}+\stackrel{\circ}{\mathrm{a}}_{t, 2} & \text { jika } Z_{t-d}>r_{1}\end{cases}
$$

SETAR $\left(2, p_{L}, p_{U}\right)$ menunjukkan model SETAR dengan 2 regime, regime pertama mengikuti model $\operatorname{AR}\left(p_{L}\right)$ dan regime kedua mengikuti model $\operatorname{AR}\left(p_{U}\right)$. Model deret waktu pada persamaan (2) dikatakan mengikuti model SETAR $\left(2, p_{L}, p_{U}\right)$ yaitu SETAR 2 regime (lower dan upper); $\operatorname{AR}\left(p_{L}\right)$ dan $\operatorname{AR}\left(p_{U}\right)$ parameter delay d dan treshold $r_{1}$

Dalam bentuk matriks, Persamaan (2) dapat ditulis sebagai

$$
\boldsymbol{Z}=\boldsymbol{Z}^{*} \ddot{\mathrm{o}}+\stackrel{\mathrm{a}}{ }
$$

dengan $\boldsymbol{Z}$ adalah matriks variabel dependen berukuran $T x 1, \boldsymbol{Z}^{*}$ adalah matriks lag variabel dependen berukuran $T x P$, ö adalah matriks parameter lag variabel dependen berukuran $P \times 1$, dan å adalah matriks error berukuran $1 x T\left(T=T_{1}+T_{2}\right.$ dan $\left.P=p_{1}+p_{2}+2\right)$. 


\subsection{Estimasi Parameter Model 2-Regime SETAR}

\subsubsection{Tahap 1}

Salah satu metode estimasi yang pada umumnya digunakan dalam mengestimasi parameter adalah metode least square. Metode ini dianggap sebagai metode terbaik dengan nilai penyimpangan terkecil jika dibandingkan dengan metode lainnya, karena metode kuadrat terkecil memperhitungkan aspek error terkecil. Dengan demikian, untuk estimasi parameter model SETAR adalah menentukan persamaan error. Dari Persamaan (2) dapat ditulis persamaan error sebagai berikut.

$$
\text { å }=\boldsymbol{Z}-\boldsymbol{Z}^{*} \ddot{\mathrm{o}}
$$

dengan $\boldsymbol{Z}$ adalah matriks variabel dependen berukuran $T \times 1, \boldsymbol{Z}^{*}$ adalah matriks lag variabel dependen berukuran $T \times P$, ö adalah matriks parameter lag variabel dependen berukuran $P \times 1$, dan å adalah matriks error berukuran $\left(T=T_{1},+T_{2}+\ldots+T_{m}\right.$ dan $\left.P=p_{1}+p_{2}+\ldots+p_{m}+m\right)$.

Dengan demikian, dapat ditentukan persamaan jumlah kuadrat error (JKE) yang ditulis sebagai

atau

$$
J K E=\sum_{i=1} \mathrm{a}_{i}^{2} \text { atau } J K E=\mathrm{å}^{\prime} \mathrm{a}=\left(\boldsymbol{Z}-\boldsymbol{Z}^{*} \ddot{\mathrm{o}}\right)^{\prime}\left(\boldsymbol{Z}-\boldsymbol{Z}^{*} \mathrm{o}\right)
$$

$$
J K E=Z^{T} Z-Z^{T} Z^{*} \ddot{o}-\ddot{o}^{T} Z^{* T} Z+\ddot{o}^{T} Z^{* T} Z^{*} \ddot{o}
$$

Untuk memperoleh estimator ö, dilakukan dengan meminimumkan JKE pada Persamaan (2) terhadap ö ${ }^{T}$. Dengan demikian, estimator model SETAR tahap pertama dituliskan sebagai

$$
\widehat{\hat{0}}=\left[Z^{* T} Z^{*}\right]^{-1} Z^{* T} Z
$$

dengan $\boldsymbol{Z}$ adalah matriks variabel dependen berukuran $t \times 1, \boldsymbol{Z}^{*}$ adalah matriks lag variabel dependen berukuran $t \times w,\left(\mathrm{w}=p_{1}+p_{2}+2\right)$. Apabila pada estimasi parameter tahap pertama paling tidak terdapat satu parameter yang tidak signifikan terhadap model, dilakukan estimasi parameter tahap kedua.

\subsubsection{Tahap 2}

Estimasi parameter tahap kedua digunakan untuk mengoptimalkan nilai parameter yang tidak signifikan terhadap model. Estimasi parameter model SETAR tahap kedua dilakukan dengan menambahkan pembatas linear yaitu

$$
\ddot{o}=R \hat{a}+\boldsymbol{a}
$$

dengan $\mathbf{R}$ adalah matriks berukuran $w \times w$, â adalah matriks parameter yang belum diketahui berukuran $w \times$ 1 , dan a adalah matriks nol yang berukuran $w \times 1$, dengan $\quad w=p_{1}+p_{2}+2$.

Langkah pertama adalah mensubstitusi Persamaan (7) ke Persamaan (4) dan diperoleh

$$
\stackrel{̊}{\mathrm{a}}=\boldsymbol{Z}-\boldsymbol{Z}^{*}(\boldsymbol{R} \hat{\mathrm{a}}+\boldsymbol{a})
$$

Kemudian ditentukan persamaaan JKE pada tahap kedua $\left(J K E_{2}\right)$ yang dapat ditulis sebagai

$$
\begin{aligned}
& J K E_{2}=Z^{T} Z-Z^{T} Z^{*} R \hat{a}-Z^{T} Z^{*} a-\hat{a}^{T} R^{T} Z^{* T} Z \\
& \quad+\hat{a}^{T} R^{T} Z^{* T} Z^{*} R \hat{a}+\hat{a}^{T} R^{T} Z^{* T} Z^{*} a-a^{T} Z^{* T} Z \\
& \quad+a^{T} Z^{* T} Z^{*} R \hat{a}-a^{T} Z^{* T} Z a
\end{aligned}
$$

Untuk memperoleh estimator â, dengan cara yang sama seperti tahap 1 dilakukan dengan meminimumkan JKE pada persamaan (9) terhadap $\hat{a}^{T}$. Dengan demikian, estimator model SETAR adalah

$$
\hat{\hat{a}}=\left[R^{T} Z^{* T} Z^{*} R\right]^{-1} R^{T} Z^{* T} Z
$$

dengan $\mathbf{R}$ adalah matriks identitas berukuran $w \times w$. $\mathbf{Z}$ adalah variabel dependen berukuran $t \times 1$, dan $\boldsymbol{Z}^{*}$ adalah matriks lag variabel dependen berukuran $t \times w$ dengan $w=p_{1}+p_{2}+2$. 


\subsection{Penerapan}

Dalam penerapan ini digunakan data ekspor agrikultur Indonesia sebagaimana telah dinyatakan pada metode penelitian, demikian juga langkah penelitiannya.

\subsubsection{Pengujian Stasioneritas Data}

Pengujian stasioneritas data dilakukan melalui dua pengujian yaitu pengujian stasioneritas terhadap variansi dan rata-rata. Pengujian stasioneritas terhadap variansi pada data ekspor agrikultur di Indonesia menggunakan plot Box-Cox dengan memerhatikan nilai ë. Hasil nilai ë pada data ekspor agrikultur di Indonesia ditunjukkan pada Tabel 1.

Tabel 1. Hasil Pengujian Stasioneritas Terhadap Variansi

\begin{tabular}{ccc}
\hline Data ekspor agrikultur & $\begin{array}{c}\text { Nilai } \\
\boldsymbol{\lambda}\end{array}$ & $\begin{array}{c}\text { Transformasi } \\
\text { data }\end{array}$ \\
\hline Sebelum transformasi & 0.5 & Tidak stasioner \\
\hline Transformasi kedua & 1 & Stasioner \\
\hline
\end{tabular}

Berdasarkan Tabel 1, data ekspor tersebut stasioner terhadap varinasi setelah dilakukan transformasi sebanyak dua kali. Selanjutnya dilakukan pengujian stasioneritas terhadap rata-rata. Untuk mengetahui data hasil transformasi stasioner terhadap rata-rata atau tidak, dilakukan uji akar unit Augmented Dickey-Fuller (ADF). Diperoleh nilai ADF sebesar -5.23 lebih lecil dari nilai kritis Mackinnon -3.44 sehingga disimpulkan bahwa $H_{0}$ ditolak yang berarti data ekspor telah stasioner terhadap rata-rata.

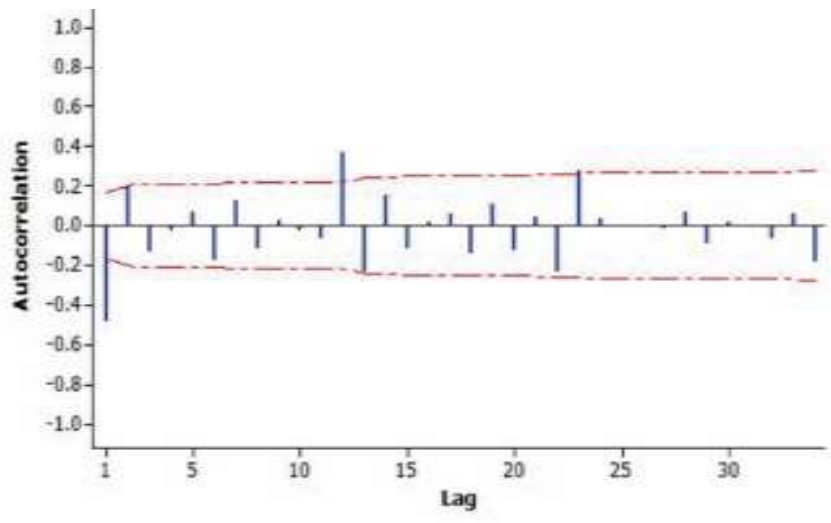

(a)

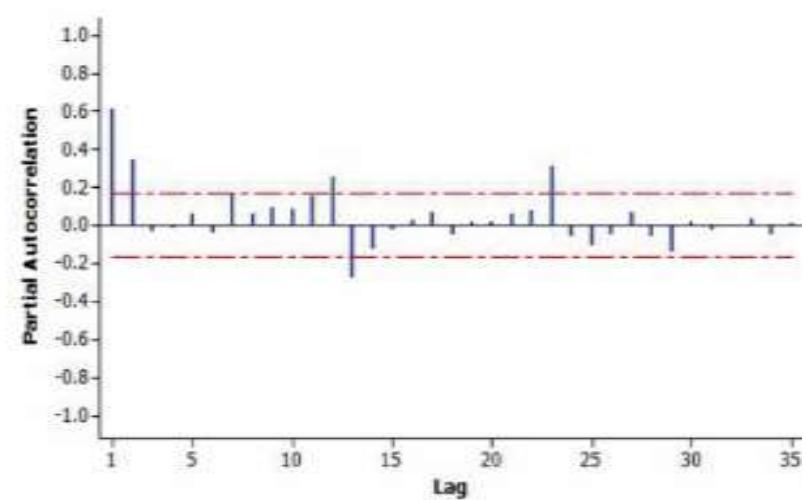

(b)

Gambar 1 (a) Plot ACF dan (b) Plot PACF

Berdasarkan Gambar 1(a), nampak bahwa plot ACF turun secara eksponensial dan berdasarkan Gambar 1(b) plot PACF terputus pada lag ke-2. Hal tersebut mengidentifikasikan bahwa model yang terbentuk pada data ekspor adalah model AR dengan orde 2 (AR(2)).

\subsubsection{Pengujian Nonlinearitas Terasvirta}

Pengujian nonlinearitas Terasvirta dilakukan dengan uji $\mathrm{F}$ dan diperoleh hasil bahwa $F_{\text {hit }}=9.74$ yang nilainya lebih besar dari $F_{(0.05,2,141)}=3.06$ sehingga dapat dinyatakan bahwa $H_{0}$ ditolak. Hal ini berarti bahwa data ekspor agrikultur berpola nonlinear.

\subsubsection{Identifikasi Model SETAR}

Identifikasi model SETAR digunakan untuk menentukan orde AR, delay, dan threshold pada model SETAR didasarkan pada nilai AIC terkecil. Hasil identifikasi model SETAR ditunjukkan pada Tabel 2. 
Tabel 2. Hasil identifikasi model SETAR

\begin{tabular}{ccccc}
\hline Delay & $\boldsymbol{p}_{\mathbf{1}}$ & $\boldsymbol{p}_{\mathbf{2}}$ & Threshold & AIC \\
\hline 1 & 1 & 1 & 19.72 & 111.37 \\
\hline 1 & 1 & 1 & 19.85 & 111.61 \\
\hline 1 & 1 & 1 & 19.95 & 111.74 \\
\hline 1 & 1 & 1 & 20.10 & 111.86 \\
\hline 1 & 1 & 1 & 19.80 & 112.02 \\
\hline 1 & 1 & 1 & 19.42 & 112.09 \\
\hline 1 & 1 & 1 & 20.00 & 112.14 \\
\hline 1 & 1 & 1 & 20.05 & 112.17 \\
\hline 1 & 1 & 1 & 20.12 & 112.18 \\
\hline 1 & 1 & 2 & 19.72 & 112.21 \\
\hline & & & &
\end{tabular}

Berdasarkan Tabel 2 tersebut, diperoleh model SETAR yaitu $\operatorname{SETAR}(2,1,1)$ dengan nilai delay sebesar 1, threshold sebesar 19.72, dan AIC sebesar 111.37.

\subsubsection{Estimasi Parameter Model SETAR}

Estimasi parameter model SETAR tahap pertama menggunakan metode kuadrat terkecil (MKT). Setelah dilakukan estimasi parameter tahap pertama dilakukan pengujian signifikansi parameter menggunakan uji t. Hasil estimasi model SETAR tahap pertama dan keputusannya ditunjukkan pada Tabel 3.

Tabel 3. Nilai Estimasi Parameter Model SETAR Tahap Pertama dan Keputusannya

\begin{tabular}{ccccc}
\hline Parameter & $\begin{array}{c}\text { Nilai estimasi } \\
\text { parameter }\end{array}$ & $\begin{array}{c}\text { Standar } \\
\text { error }\end{array}$ & Nilai $\boldsymbol{t}_{\text {hit }}$ & Keputusan uji \\
\hline$\widehat{\widehat{\mathrm{O}}}_{0,1}$ & 5.34 & 2.06 & 2.59 & Signifikan \\
\hline$\widehat{\mathrm{O}}_{1,1}$ & 0.39 & 0.90 & 4.31 & Signifikan \\
\hline$\widehat{\hat{\mathrm{O}}}_{0,2}$ & 0.42 & 0.14 & 0.58 & Tidak signifikan \\
\hline$\widehat{\mathrm{O}}_{1,2}$ & 0.81 & 0.25 & 3.20 & Signifikan \\
\hline
\end{tabular}

Pada Tabel 3, nampak bahwa parameter $\widehat{\hat{o}}_{0,1}, \widehat{\hat{o}}_{1,1}, \widehat{\hat{o}}_{1,2}$ signifikan dengan nilai lebih besar dari $t_{(0,025,137)}=1.98$ sementara parameter lainnya, yakni, $\hat{\hat{O}}_{0,2}$ tidak signifikan dengan nilai lebih kecil dari $t_{(0,025,136)}=1.98$. Dengan demikian, terdapat tiga parameter yang tidak signifikan selanjutnya perlu dilakukan estimasi parameter model SETAR tahap kedua. Hasil estimasi parameter model SETAR tahap kedua beserta keputusannya ditunjukkan pada Tabel 4.

Tabel 4. Nilai Estimasi Parameter Model SETAR Tahap Kedua dan Keputusan Uji

\begin{tabular}{crccc}
\hline Parameter & $\begin{array}{c}\text { Nilai estimasi } \\
\text { parameter }\end{array}$ & Standar error & Nilai $t_{\text {hit }}$ & Keputusan uji \\
\hline$\widehat{0}_{0,2}$ & 3.33 & 5.77 & 4.23 & Signifikan \\
\hline
\end{tabular}

Pada Tabel 4, nampak bahwa parameter $\widehat{\hat{O}}_{0,2}$ signifikan dengan nilai $\left|t_{h i t}\right|$ lebih besar dari $t_{(0.025,39)}=$ 2.02. Selain itu, parameter $\hat{\hat{a}}_{0,2}$ dan $\hat{\hat{a}}_{2,2}$ juga signifikan dengan nilai lebih besar dari $t_{(0,025,83)}=1.99$. Semua parameter model SETAR telah signifikan sehingga model SETAR pada data ekspor agrikultur di Indonesia adalah SETAR $(2,1,1)$ yang dituliskan sebagai

$$
Z_{t}= \begin{cases}5,34+0,389 Z_{t-1} & \text { jika } Z_{t-1}>386 \\ 3,33+0,81 Z_{t-1} & \text { jika } Z_{t-1} \leq 386\end{cases}
$$

\subsubsection{Pengujiam Asumsi Error Model SETAR}

Pengujian asumsi error model SETAR $(2,1,1)$ bertujuan untuk mengetahui apakah error $\stackrel{\circ}{t}_{t}$ memenuhi proses white noise dan berdistribusi normal (normalitas). Pengujian asumsi white noise dilakukan dengan uji Ljung-Box (LB). Hasil pengujian menunjukan bahwa statistik uji LB, $3.4939<\chi^{2}{ }_{(0.5,10)}=18.307$ yang berarti bahwa $H_{0}$ tidak ditolak yakni model $\operatorname{SETAR}(2,1,1)$ white noise. Dengan demikian asumsi white noise 
dipenuhi. Selanjutnya dilakukan pengujian asumsi normalitas dilakukan dengan uji Kolmogorov-Smirnov. Hasil pengujian asumsi normalitas menunjukkan bahwa model statistik uji KS, 1,7672< $<D_{(0,05,12)}=0.375$ yang berarti $H_{0}$ tidak ditolak yakni model SETAR $(2,1,1)$ berdistribusi normal. Dengan demikian dua asumsi error model SETAR $(2,2,2)$ yakni white noise dan berdistribusi normal dipenuhi.

\subsubsection{Validasi Model SETAR}

Validasi model dilakukan untuk mengukur kevalidan model peramalan. Validasi model SETAR $(2,1,1)$ menggunakan data ekspor agrikultur Indonesia dari periode Januari 2019 sampai dengan Desember 2019 dan diperoleh nilai MAPE 25\% yang berarti bahwa model $\operatorname{SETAR}(2,1,1)$ cukup baik digunakan untuk peramalan pada data ekspor agrikultur di Indonesia. Plot data agrikultur 2019 dengan peramalannya ditunjukkan pada Gambar 2.

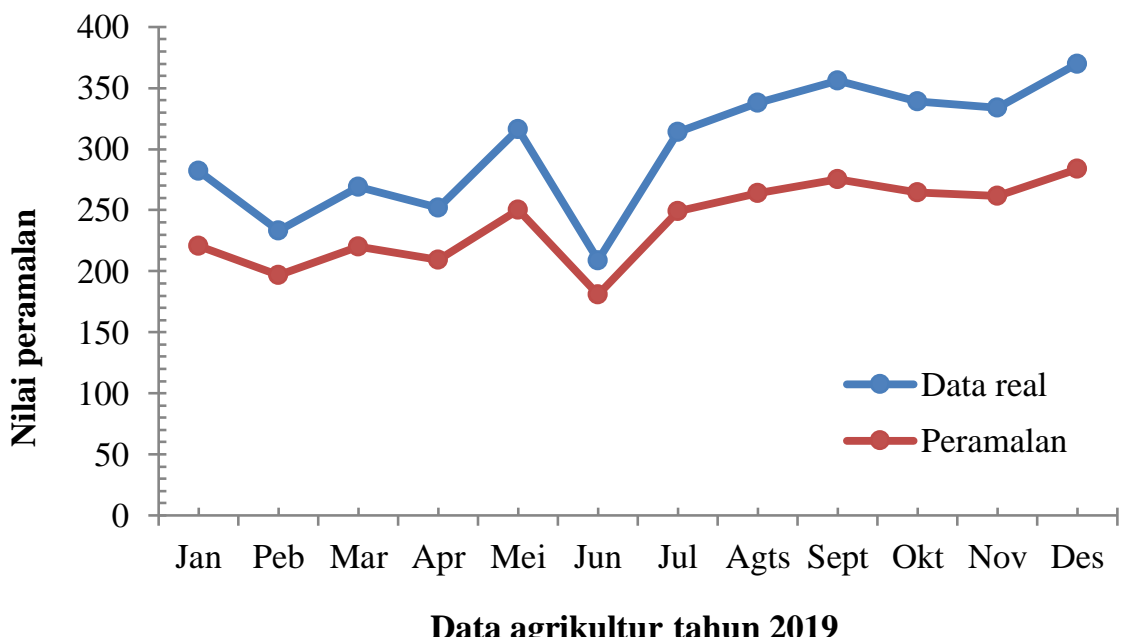

Gambar 2. Plot Data Agrikultur 2019 dan Data Peramalan SETAR $(2,1,1)$

\section{KESIMPULAN}

Berdasarkan hasil dan pembahasan, diperoleh dua kesimpulan. Kesimpulan yang pertama yaitu etimasi parameter model SETAR dilakukan dengan menggunakan MKT dua tahap dengan estimator model SETAR tahap pertama adalah $\hat{\mathrm{o}}=\left[\boldsymbol{Z}^{* \boldsymbol{T}} \boldsymbol{Z}^{*}\right]^{-\mathbf{1}} \boldsymbol{Z}^{* \boldsymbol{T}} \boldsymbol{Z}$ dan estimator model SETAR tahap kedua adalah $\hat{\hat{a}}=$ $\left[\boldsymbol{R}^{T} \boldsymbol{Z}^{* \boldsymbol{T}} \boldsymbol{Z}^{*} \boldsymbol{R}\right]^{-1} \boldsymbol{R}^{T} \boldsymbol{Z}^{* T} \boldsymbol{Z}$, dengan $\mathbf{R}$ adalah matriks identitas berukuran $w \times w$. $\mathbf{Z}$ adalah variabel dependen berukuran $t \times 1$, dan $\boldsymbol{Z}^{*}$ adala matriks lag variable dependen berukuran $t \times w$. Kesimpulan yang kedua yaitu model SETAR yang diterapkan pada data ekspor agrikultur di Indonesia adalah $\operatorname{SETAR}(2,1,1)$ seperti pada persamaan sebagai berikut.

$$
Z_{t}=\left\{\begin{array}{cc}
5,34+0,389 Z_{t-1} & \text { jika } Z_{t-1}>386 \\
3,33+0,81 Z_{t-1} & \text { jika } Z_{t-1} \leq 386
\end{array}\right.
$$

dengan nilai MAPE $25 \%$.

\section{DAFTAR PUSTAKA}

[1] Granger, C.W.J, dan Teräsvirta T., "A simple nonlinier time series model with misleading linier properties". Economics Letters 62, 161-165, 1999

[2] E.H. Firat . "SETAR (Self-exciting Threshold Autoregressive) Non-linear Currency Modelling in EUR/USD, EUR/TRY and USD/TRY Parities." Mathematics and Statistics, pp. 33-55. doi: 10.13189/ms.2017.050105, 2017

[3] E.H. Bruce, "Threshold Autoregressive in Economoics", Journal of Econometrices, 123 - 127, 2011.

[4] G. Boero, F. Lampis, "The Forecasting Performance of SETAR Models: An Empirical Application”, Bulletin of Economic Research, January 2016 
[5] G.C. Tiao, R.S. Tsay, "Some Advances in Nonlinear and Adaptive Modelling in Time Series", Journal of Forecasting,13, pp. 109-131, 1994.

[6] H. Chen, T.T.L. Chong, and J.X. Bai."Theory and Applications of TAR Model with Two Threshold Variables". Munich Personal RePEc Archive (MPRA). Tersedia : https://mpra.ub.unimuenchen.de/54527/1/MPRA_paper_54527.pdf [Diakses : 27 Januari 2020]

[7] H. Feng, J. Liu, "A SETAR Model for Canadian GDP: Non-linearities and Forecast Comparisons", University of Victoria, Working Paper EWP 0206, ISSN 1485-6441, 2002.

[8] H. Tong, Threshold Models in Nonlinear Time Series Analysis, Springer, New York, 1983.

[9] H. Tong, I. Yeung, "On tests for Self-exciting Threshold Autoregressive-Type Non-linearity in Partially Observed Time Series”. Applied Statistics, no. 40, pp. 43-62, 1991.

[10] J. E. Hanke, and D. W. Wichern, Business Forecasting Eighth Edition, Pearson Education International, New Jersey, 2005.

[11] K. Chan, R.S. Tsay, "Limiting Properties of the Least Squares Estimator of a Continuous Threshold Autoregressive Model", Biometrika, no. 85, pp. 413-426, 1998.

[12] Kemendag [Kementrian Perdagangan Republik Indonesia. 2019. Pengertian Ekspor. www.kemendag.go.id. [2 Februari 2019].

[13] M. P. Clements, J. Smith, "A Monte Carlo study of the forecasting performance of empirical SETAR models", University of Warwick, Publications Service \& WRAP, Warwick economic research papers, 1997

[14] Q. Fu, H. Fu, and Y. Sun, Self-Exciting Threshold Autoregressive Model (SETAR) to Forecast the Well Irrigation Rice Water Requirement, Northest Agrikultur University, China, 2004.

[15] R. S. Tsay, Analysis of Financial Time Series Second Edition, John Wiley and Sons, Canada, 2005.

[16] S. Makridakis, S. C. Wheelwright, and V. E. McGee, Forecasting: Methods and applications, Second Edition, John Wiley and Sons, New York, 1983.

[17] T. Putri, and Irhamah, "Identification of Self-Exciting Threshold Autoregressive Model in Stock Return Data by Using Genetic Algorithm”, Presented in International Conference: Pure, Apllied, and Computation, Surabaya, 2016.

[18] T.I Mohd \& I. Zaidi, "Modelling Exchange Rates Using Regime Switching Models", Sains Malaysiana, 35 (2), pp. 55-62, 2006.

[19] T. Tambunan, Perkembangan Ekspor dan Impor Indonesia dan Permasalahannya, Jurnal Fakultas Ekonomi, Universitas Trisakti, Jakarta, 2006. 11

[20] W.S. Wei, Time Series Analysis: Univariate and Multivariate Method, Addison Wesley Publishing Company, New York, 1994. 
